\section{Does Maintaining a Bottle of Adhesive Without the Lid Significantly Reduce the Solvent Content?}

\author{
Márcia Luciana Carregosa Santana ${ }^{1}$, José Aginaldo de Sousa Júnior ${ }^{1}$, Pollyana \\ Caldeira Leal ${ }^{2}$, André Luis Faria-e-Silva ${ }^{1}$
}

\author{
'Department of Dentistry, \\ UFS - Federal University of \\ Sergipe, Aracaju, SE, Brazil \\ ${ }^{2}$ Department of Physiology, UFS \\ - Federal University of Sergipe, \\ São Cristóvão, SE, Brazil
}

Correspondence: André Luis Faria e Silva, Rua Cláudio Batista, s/n Sanatório, 49060-100 Aracaju, SE, Brasil. Tel.: +: 55-79-2105-1821. e-mail: fariaesilva.andre@gmail.com

\begin{abstract}
This study aimed to evaluate the effect of maintaining a bottle of adhesive without its lid on the solvent loss of the etch-and-rinse adhesive systems. Three 2-step etch-and-rinse adhesives with different solvents (acetone, ethanol or butanol) were used in this study. Drops of each adhesive were placed on an analytical balance and the adhesive mass was recorded until equilibrium was achieved (no significant mass alteration within time). The solvent content of each adhesive and evaporation rate of solvents were measured $(n=3)$. Two bottles of each adhesive were weighted. The bottles were maintained without their lids for $8 \mathrm{~h}$ in a stove at $37^{\circ} \mathrm{C}$, after which the mass loss was measured. Based on mass alteration of drops, acetone-based adhesive showed the highest solvent content (46.5\%, Cl 95\%: 35.8-54.7) and evaporation rate (1.11 \%/s, Cl95\%: 0.63-1.60), whereas ethanol-based adhesive had the lowest values (10.1\%, Cl95\%: 4.3-16.0; $0.03 \% / \mathrm{s} \mathrm{Cl95 \% :}$ $0.01-0.05)$. However, none of the adhesives bottles exhibited significant mass loss after sitting for $8 \mathrm{~h}$ without their lids (\% from initial content; acetone - 96.5, Cl 95\%: 91.8101.5; ethanol - 99.4, Cl 95\%: 98.4-100.4; and butanol - 99.3, Cl 95\%: 98.1-100.5). In conclusion, maintaining the adhesive bottle without lid did not induce significant solvent loss, irrespective the concentration and evaporation rate of solvent.
\end{abstract}

Key Words: adhesives, solvents, volatilization.

\section{Introduction}

Even with the evolution of adhesive systems in last decades, the establishments of a predictable bonding interface in dentin tissue remains a challenge for the clinicians (1-3). Self-etching adhesive systems has gained popularity; however, etch-and-rinse adhesives are still a suitable option to adhesive procedures on clinical practice. For etch-and-rinse adhesives, a phosphoric acid is applied previously to adhesive system and removes partially the mineral content of dentin tissue to expose the collagen mesh $(4,5)$. Interfibrillar spaces in the collagen mesh are maintained by water, while organic solvents in the adhesive displace this water from the demineralized dentin to allow the infiltration of resin monomers $(5,6)$. Furthermore, these solvents also help the water evaporation from dentin allowing a proper adhesive polymerization (7-9). Thus, a reduction in the solvent content can compromise the infiltration of adhesive resin and the effectiveness of the dentin bond (10).

Acetone and alcohols are the main organic solvents used in adhesive systems due to high volatility and low cost. These solvents present different volatilities and are added to adhesives in concentrations ranging from 30 to $80 \%(10,11)$. This variation is due to fact that more volatile solvents are commonly added in higher concentrations $(10,11)$. However, it has been reported that the repeated opening of the adhesive bottle during the clinical procedure can permit the spontaneous evaporation of solvents (10-13). However, few information is actually available about a possible the solvent loss over time when the adhesive bottle is maintained in an open state. Thus, the aim of this study was to investigate the effect of maintaining an adhesive bottle without its lid in terms of the solvent content. The hypothesis was that significant loss of solvent would occur when the bottle was left open over time under simulated warm environment to accelerate the solvent evaporation.

\section{Material and Methods}

Three 2-step etch-and-rinse adhesives with different solvent types were used in this study. The composition and manufacturers of each adhesive are described at Table 1. To determine the solvent content of the adhesive and the evaporation rate of each solvent, one drop of each adhesive was dispensed in an analytical balance (JEX-200, YMC Co. Ltd, Kyoto, Japan) and mass alteration of drop was evaluated. The adhesive mass was recorded at 5-s intervals until it reached equilibrium at room temperature. The equilibrium was determined when no alteration of mass occurred within time. The solvent content was determined as the ratio between the final and initial weights (Solvent content in $\%=$ (final weight/ initial weight $\left.)^{*} 100\right)$. The average evaporation rate was calculated as the weight loss at the moment of equilibrium, divided by the time (in s) to reach this point. The solvent content and evaporation 
rate were measured in triplicate.

To determine the solvent loss when the bottle was maintained without its lid, two full bottles of each adhesive were placed individually over the analytical balance to measure the initial weight. The lids were removed, and the bottles were placed in a stove at $37^{\circ} \mathrm{C}$ for $8 \mathrm{~h}$. After this storage period, the bottles were weighted again with the lids. The full adhesive content was removed from the bottle, and the empty bottles were weighted. The adhesive/solvent content of the bottles was determined by subtracting the weight of the empty bottle from the weight of the full bottle before and after the storage in stove. The ratio between the final and initial weights of adhesive/solvent was used to determine the solvent loss. Data of solvent content, rate of evaporation, and solvent loss were submitted to one-way analysis of variance (ANOVA) and Tukey's test $(\alpha=0.05)$. Data analysis was performed using the SigmaStat v.3.5 statistical software package (Systat Software Inc., Chicago, IL, USA).

\section{Results}

ANOVA showed significant effect for adhesive $(p<0.001)$ regarding the solvent content. Stae showed the highest and Ambar the lowest solvent concentration, while XP bond

Table 1. Manufacturers and composition of the adhesives used in this study presented intermediate values. For evaporation rate, ANOVA also showed significant effect for adhesive $(p<0.001)$. Stae (acetone) demonstrated the highest evaporation rate among the adhesives evaluated followed by XP Bond (butanol) and Ambar (ethanol), which showed the lowest evaporation rate values. ANOVA did not show significant effect for adhesive $(p=0.191)$ regarding the solvent loss after $8 \mathrm{~h}$. The superior limit of the confidence interval (95\%) calculated was higher than $100 \%$ for all adhesives, demonstrated absence of significant difference from the initial content. The results are presented in Table 2 . Figure 1 illustrates the solvent loss of adhesive drop within the time.

\section{Discussion}

The adhesives evaluated in this study showed significant differences in solvent concentration. The acetone-based adhesive showed the highest solvent content, whereas the ethanol-based solvent presented the lowest content. These findings confirm previous reports that acetone-based adhesives present higher solvent content because of the relatively high vapor pressure of acetone $(184.3 \mathrm{mmHg}$ at $20^{\circ} \mathrm{C}$ ), which results in elevated volatility (14). Interestingly, the ethanol in Ambar presented a lower evaporation

\begin{tabular}{lcc}
\hline Adhesive & Manufacturer & Composition* $^{*}$ \\
\hline Stae & $\begin{array}{c}\text { SDl, Bayswater, } \\
\text { Victoria, Australia }\end{array}$ & Acetone, water, proprietary hydrophilic/hydrophobic monomer, \\
XP Bond & $\begin{array}{c}\text { Dentsply De Trey, } \\
\text { Konstanz, Germany }\end{array}$ & PENTA, TCB, HEMA, TEGDMA, UDMA, tert-butanol, nanofiller, photoinitiators, coinitiators, stabilizers \\
Ambar & $\begin{array}{c}\text { FGM, Joinville, } \\
\text { SC, Brazil }\end{array}$ & $\begin{array}{c}\text { UDMA, HEMA, Acid methacrylated monomers, Hydrophilic methacrylated monomers, } \\
\text { ethanol, silica nanofiller, photoinitiators, coinitiators, Stabilizers }\end{array}$
\end{tabular}

*Information provided by the manufacturer. Abbreviations: 2-hydroxyethyl methacrylate (HEMA), dipentaerythritol penta acrylate monophosphate (PENTA), butan-1,2,3,4-tetracarboxylic acid di-2-hydroxyethylmethacrylate ester (TCB), triethylene glycol dimethacrylate (TEGDMA), urethane dimethacrylate (UDMA).

Table 2. Results in means (95\% Confidence interval)

\begin{tabular}{|c|c|c|c|}
\hline Adhesive & $\begin{array}{c}\text { Solvent } \\
\text { content (\%) }\end{array}$ & $\begin{array}{l}\text { Evaporation } \\
\text { rate }(\% / \mathrm{s})\end{array}$ & $\begin{array}{l}\text { Final/initial solvent } \\
\text { content on bottle }(\%)\end{array}$ \\
\hline Stae & $\begin{array}{c}46.5 \\
(35.8-54.7) A\end{array}$ & $\begin{array}{c}1.11 \\
(0.63-1.60) \mathrm{A}\end{array}$ & $\begin{array}{c}96.5 \\
(91.8-101.5) A\end{array}$ \\
\hline XP Bond & $\begin{array}{c}20.7 \\
(15.8-25.6) \mathrm{B}\end{array}$ & $\begin{array}{c}0.07 \\
(0.05-0.09) \mathrm{B}\end{array}$ & $\begin{array}{c}99.3 \\
(98.1-100.5) A\end{array}$ \\
\hline Ambar & $\begin{array}{c}10.1 \\
(4.3-16.0) \mathrm{C}\end{array}$ & $\begin{array}{c}0.03 \\
(0.01-0.05) \mathrm{C}\end{array}$ & $\begin{array}{c}99.4 \\
(98.4-100.4) A\end{array}$ \\
\hline
\end{tabular}

Distinct letter indicate statistically significant difference $(\alpha=0.05)$. Confidence Interval is an interval that estimates of the population parameter.

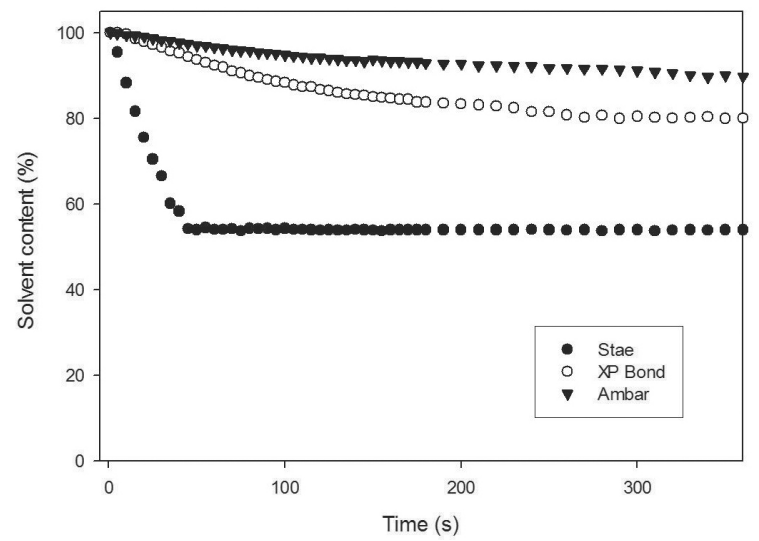

Figure 1. Solvent loss from adhesive drops. 
rate than the butanol in XP Bond. The vapor pressure of ethanol $\left(43.7 \mathrm{mmHg}\right.$ at $\left.20^{\circ} \mathrm{C}\right)$ is almost 10 -fold higher than that of butanol $(4.9 \mathrm{mmHg})(14-15)$. However, it has been demonstrated that the addition of water to ethanol as co-solvent increases the retention of both solvents (16). This occurs because the water evaporation increases the monomer/water ratio and reduces the vapor pressure of water, reducing the ability of water and ethanol to evaporate from adhesive (17).

Considering the solvent volatility, it was expected that maintaining the adhesive bottle without a lid would result in a significant loss of solvent, especially for the acetonebased adhesive. However, no significant solvent loss was observed over the 8-h experiment. Thus, the hypothesis of the study was rejected. Despite the high volatility of organic solvents used in these adhesive systems, bottles are designed to reduce solvent lost. The "smart" designs of bottles have been developed seeking to reduce the solvent loss from the adhesive bottles during the clinical procedures. Clinically, the bottle was not maintained open for long periods of time as in the simulation of present study. However, the maintenance of bottle without lid for shorter periods during for several times results long time to volatilization of solvents. Despite the possibility to maintain the bottle open for long time, the results demonstrate the efficacy of these "smart" designs to not allow a significant solvent content loss. A previous study also demonstrated reduced solvent loss from the adhesive bottle (11).

Significant loss of solvent content from 2-step etchand-rinse adhesives has a detrimental effect on the bond strength to dentin tissue (10). Thus, it has been advocated that the lid of the bottle be replaced immediately after dispensing the adhesive, to avoid solvent loss (13). The outcomes of the present study indicate that maintaining the adhesive bottle without a lid does not result in significant solvent loss. However, these findings must be viewed with caution because there may be other factors (i.e. agitation of bottle before to remove lid, storage of adhesive without refrigeration, etc.) that were not evaluated which may also affect the solvent loss.

\section{Resumo}

Este estudo avaliou o efeito da manutenção do frasco do adesivo sem sua tampa na perda de solvente de sistemas adesivos convencionais. Três adesivos convencionais de 2 passos com diferentes solventes (acetona, etanol ou butanol) foram usados neste estudo. Gotas de cada adesivo foram colocadas em uma balança analítica e a massa dos adesivos foi registrada até a obtenção do equilibrio (nenhuma alteração significativa com o tempo). 0 conteúdo de solvente de cada adesivo e a taxa de evaporação dos solventes foram mensurados $(n=3)$. Dois frascos de cada adesivo foram pesados. Os frascos foram mantidos sem suas tampas por $8 \mathrm{~h}$ em uma estufa a $37^{\circ} \mathrm{C}$, seguido pela mensuração da pera de massa. Baseado na alteração de massa das gotas, o adesivo a base de acetona demonstrou o maior conteúdo de solvente $(46,5 \%$, IC 95\%: 35,8-54,7) e de taxa de evaporação $(1,11 \% / \mathrm{s}$, IC95\%:0,63-1,60), enquanto que o adesivo à base de etanol teve os menores valores (10,1\%, IC95\%: 4,3-16,0; 0,03 \%/s IC95\%: 0,01-0,05). Entretanto, nenhum dos frascos dos adesivos exibiu perda significante de massa após ficar por $8 \mathrm{~h}$ sem suas tampas (\% do conteúdo inicial; acetona - 96,5 IC95\%: 91,8-101,5; etanol - 99,4, IC95\%: 98,4-100,4; e butanol - 99,3, IC95\%: 98,1-100,5). Em conclusão, a manutenção do frasco do adesivo sem tampa não induziu perda significante de solvente independente da concentração e da taxa de evaporação do solvente.

\section{Acknowledgements}

M.L.C.S. (CNPq/Brazil) and J.A.S.J. (COPES/UFS/Brazil) are grateful to the funding agencies for their scholarships.

\section{References}

1. Pomacóndor-Hernández C, Antunes AN, Hipólito Vd, Goes MF. Effect of replacing a component of a self-etch adhesive by chlorhexidine on bonding to dentin. Braz Dent J 2013;24:335-339.

2. Zhang L, Wang DY, Fan J, Li F, Chen YJ, Chen JH. Stability of bonds made to superficial vs. deep dentin, before and after thermocycling. Dent Mater 2014;30:1245-1251.

3. Borges FB, Kochhann DE, Lima EL, Machado FW, Boscato N, Van De Sande $\mathrm{FH}$, et al.. Effect of cariogenic challenge on the stability of dentin bonds. J Appl Oral Sci 2014;22:68-72.

4. Nakabayashi N, Kojima K, Masuhara E. The promotion of adhesion by infiltration of monomers into tooth substrates. J Biomed Mater Res 1982;16:265-273.

5. Van Meerbeek B, De Munck J, Yoshida Y, Inoue S, Vargas M, Vijav P, et al.. Buonocore memorial lecture. Adhesion to enamel and dentin: current status and future challenges. Oper Dent 2003;28:215-235.

6. Reis A, Loguercio AD, Azevedo CL, Carvalho RM, Julio Singer M, Grande $\mathrm{RH}$. Moisture spectrum of demineralized dentin for adhesive systems with different solvent bases. J Adhes Dent 2003;5:183-192.

7. Cadenaro M, Breschi L, Rueggeberg FA, Suchko M, Grodin E, Agee K, et al.. Effects of residual ethanol on the rate and degree of conversion of five experimental resins. Dent Mater 2009;25:621-628.

8. Bail M, Malacarne-Zanon J, Silva SM, Anauate-Netto A, Nascimento FD, Amore $\mathrm{R}$, et al.. Effect of air-drying on the solvent evaporation, degree of conversion and water sorption/solubility of dental adhesive models. J Mater Sci Mater Med 2012;23:629-638.

9. Emamieh S, Sadr A, Ghasemi A, Torabzadeh H, Akhavanzanjani V, Tagami J. Effects of solvent drying time and water storage on ultimate tensile strength of adhesives. J Investig Clin Dent 2014;5:51-57.

10. Faria-e-Silva AL, Araújo JE, Rocha GP, Oliveira Ada S, Moraes RR. Solvent content and dentin bond strengths using water-wet, ethanolwet and deproteinization bonding techniques. Acta Odontol Scand 2013;71:710-715.

11. Reis AF, Oliveira MT, Giannini M, De Goes MF, Rueggeberg FA. The effect of organic solvents on one-bottle adhesives' bond strength to enamel and dentin. Oper Dent 2003;28:700-706.

12. Nihi FM, Fabre HS, Garcia G, Fernandes KB, Ferreira FB, Wang L. In vitro assessment of solvent evaporation from commercial adhesive systems compared to experimental systems. Braz Dent J 2009;20:396-402.

13. Abate PF, Rodriguez VI, Macchi RL. Evaporation of solvent in one-bottle adhesives. J Dent 2000;28:437-440.

14. Gallo JR, Burgess JO, Xu X. Effect of delayed application on shear bond strength of four fifth-generation bonding systems. Oper Dent $2001 ; 26: 48-51$.

15. Oktavian R, Amidelsi V, Rasmito A, Wibawa G. Vapor pressure measurements of ethanol-isooctane and 1-butanol-isooctane systems using a new ebulliometer. Fuel 2013;107:47-51.

16. Yiu CK, Pashley EL, Hiraishi N, King NM, Goracci C, Ferrari M, et al.. Solvent and water retention in dental adhesive blends after evaporation. Biomaterials 2005;26:6863-6872.

17. Pashley EL, Zhang Y, Lockwood PE, Rueggeberg FA, Pashley DH. Effects of HEMA on water evaporation from water-HEMA mixtures. Dent Mater 1998;14:6-10.

Received October 22, 2014 Accepted November 10, 2014 